\title{
Identification of optimal reference RNAs to normalize miRNA expression data by qRT-PCR in formalin-fixed, paraffin-embedded lymph node tissue
}

\author{
Eliana Bignotti ${ }^{1}$, Paola Todeschini ${ }^{1}$, Chiara Romani ${ }^{2}$ \\ ${ }^{1}$ Division of Obstetrics and Gynecology, “Angelo Nocivelli” Institute of Molecular Medicine, ASST Spedali Civili di Brescia, Brescia, Italy; \\ ${ }^{2}$ Department of Obstetrics and Gynecology, "Angelo Nocivelli” Institute of Molecular Medicine, University of Brescia, Brescia, Italy \\ Correspondence to: Eliana Bignotti. Division of Obstetrics and Gynecology, “Angelo Nocivelli” Institute of Molecular Medicine, ASST Spedali Civili \\ di Brescia, Brescia, Italy. Email: bignottieliana@gmail.com. \\ Comment on: Inada K, Okoshi Y, Cho-Isoda Y, et al. Endogenous reference RNAs for microRNA quantitation in formalin-fixed, paraffin-embedded \\ lymph node tissue. Sci Rep 2018;8:5918.
}

Submitted Jun 22, 2018. Accepted for publication Jun 27, 2018.

doi: 10.21037/tcr.2018.07.01

View this article at: http://dx.doi.org/10.21037/tcr.2018.07.01

We recently read the interesting paper of Inada et al., published on Sci Rep 2018 (1), regarding the identification of optimal reference RNAs for miRNA quantification using qRT-PCR in formalin-fixed paraffin-embedded (FFPE) lymph node tissues from patients with metastatic cancer. FFPE material represents an extensive repository of tissue samples with a long-term clinical follow-up, providing a valuable resource for translational research. Even though RNA degradation occurs, due to the formalin fixation process, it is feasible to extract miRNA from FFPE tissue and to perform qRT-PCR-based expression profiling. However, a crucial point in approaching accurate miRNA expression quantification using qRT-PCR is the choice of the most stably expressed endogenous references that should be used for data normalization. Actually, most of the investigations in the literature report arbitrarily chosen endogenous controls, including miRNA, snRNA and snoRNA, without any experimental validation of their stability or they commonly use U6 snRNA, although a growing body of evidence demonstrate its high expression instability across tissues (2). Moreover, according to the Minimum Information for Publication of Quantitative Real-Time PCR Experiments (MIQE) guidelines (3), normalization against a single reference gene is not acceptable and a combination of different reference genes should be used in order to produce reliable quantification. The paper of Inada et al. found a combination of three
miRNAs as suitable endogenous references for miRNA quantification in FFPE lymph nodes. The miRNA combination, including miR-24, miR-103a and let-7a, has been obtained starting from 71 candidate miRNAs using four different statistical tools, preceded by a global mean normalization strategy. Those three miRNAs have been already reported with stable expression in tumor tissues, thus confirming authors' findings. We believe that Inada et al.'s article reflects a well-conducted study, in compliance with MIQE guidelines for accurate miRNA quantification using qRT-PCR. Moreover, one of the strength of the experimental method is the application of the Exiqon technology to miRNA quantification, ensuring the maximum sensitivity, specificity and accuracy of qRT-PCR system, as recently reported (4). Although the relatively small sample size may be considered a limitation of the study, we believe that Inada and colleagues' article could be considered a valuable starting point for other researchers who need to reliably quantify miRNA expression through qRT-PCR in FFPE lymph node tissues.

\section{Acknowledgments}

Funding: We would like to thank Umberto Veronesi Foundation for supporting Chiara Romani and Paola Todeschini. 


\section{Footnote}

Provenance and Peer Review: This article was commissioned and reviewed by the Section Editor Long Chen (Department of PET-CT Center, Yunnan Tumor Hospital, the Third Affiliated Hospital of Kunming Medical University, Kunming, China; Department of Biochemistry and Molecular Biology, Kunming Medical University, Kunming, China).

Conflicts of Interest: All authors have completed the ICMJE uniform disclosure form (available at http://dx.doi. org/10.21037/tcr.2018.07.01). The authors have no conflicts of interest to declare.

Ethical Statement: The authors are accountable for all aspects of the work in ensuring that questions related to the accuracy or integrity of any part of the work are appropriately investigated and resolved.

Open Access Statement: This is an Open Access article distributed in accordance with the Creative Commons Attribution-NonCommercial-NoDerivs 4.0 International License (CC BY-NC-ND 4.0), which permits the noncommercial replication and distribution of the article with the strict proviso that no changes or edits are made and the original work is properly cited (including links to both the formal publication through the relevant DOI and the license). See: https://creativecommons.org/licenses/by-nc-nd/4.0/.

\section{References}

1. Inada K, Okoshi Y, Cho-Isoda Y, et al. Endogenous reference RNAs for microRNA quantitation in formalinfixed, paraffin-embedded lymph node tissue. Sci Rep 2018;8:5918.

2. Lou G, Ma N, Xu Y, et al. Differential distribution of U6 (RNU6-1) expression in human carcinoma tissues demonstrates the requirement for caution in the internal control gene selection for microRNA quantification. Int $\mathrm{J}$ Mol Med 2015;36:1400-8.

3. Bustin SA, Benes V, Garson JA, et al. The MIQE guidelines: minimum information for publication of quantitative real-time PCR experiments. Clin Chem 2009;55:611-22.

4. Mestdagh P, Hartmann N, Baeriswyl L, et al. Evaluation of quantitative miRNA expression platforms in the microRNA quality control (miRQC) study. Nat Methods 2014;11:809-15.
Cite this article as: Bignotti E, Todeschini P, Romani C. Identification of optimal reference RNAs to normalize miRNA expression data by qRT-PCR in formalin-fixed, paraffinembedded lymph node tissue. Transl Cancer Res 2018;7(Suppl 7):S733-S734. doi: 10.21037/tcr.2018.07.01 